\title{
Extracts of Artemisia ciniformis Protect Cytotoxicity Induced by Hydrogen Peroxide in H9c2 Cardiac Muscle Cells through the Inhibition of Reactive Oxygen Species
}

\author{
Mahdi Mojarrab, ${ }^{1}$ Maryam Jamshidi, ${ }^{2}$ Farahnaz Ahmadi, ${ }^{1}$ \\ Ellahe Alizadeh, ${ }^{1}$ and Leila Hosseinzadeh ${ }^{1}$ \\ ${ }^{1}$ Novel Drug Delivery Research Center, School of Pharmacy, Kermanshah University of Medical Sciences, \\ Kermanshah 6734667149, Iran \\ ${ }^{2}$ Student Research Committee, Kermanshah University of Medical Sciences, Kermanshah 6734667149, Iran \\ Correspondence should be addressed to Leila Hosseinzadeh; lhosseinzadeh90@yahoo.com
}

Received 4 August 2013; Revised 19 October 2013; Accepted 19 October 2013

Academic Editor: Neal Davies

Copyright @ 2013 Mahdi Mojarrab et al. This is an open access article distributed under the Creative Commons Attribution License, which permits unrestricted use, distribution, and reproduction in any medium, provided the original work is properly cited.

Objective. Artemisia ciniformis (Asteraceae) and A. biennis are two of 34 Artemisia species growing naturally in Iran. In this study we investigated whether different extracts of $A$. ciniformis and $A$. biennis have protective effect against hydrogen peroxide-induced cytotoxicity in rat cardiomyoblast cells (H9c2). Method. The dried and ground aerial parts of these two species were extracted successively using petroleum ether (40-60), dichloromethane, ethyl acetate (EA), ethanol (EtOH) and ethanol: water (1:1) by maceration method. To evaluate whether different extracts of $A$. ciniformis and A. biennis protect cardiomyoblast $\mathrm{H} 9 \mathrm{c} 2 \mathrm{cells}$ from $\mathrm{H}_{2} \mathrm{O}_{2}$ cytotoxicity, we examined the direct cytotoxic effect of $\mathrm{H}_{2} \mathrm{O}_{2}$ on $\mathrm{H} 9 \mathrm{c} 2$ cells in the presence and absence of different extracts. After then, cell viability was measured by MTT assay. Results. $\mathrm{H}_{2} \mathrm{O}_{2}$ induced cytotoxicity in a concentration dependent manner. The $\mathrm{IC}_{50}$ value was $62.5 \mu \mathrm{M}$ for $24 \mathrm{~h}$ exposure. However, pretreatment of cells with various concentrations of EA, EtOH, and EtOH/wt extract of A. ciniformis protected cells from $\mathrm{H}_{2} \mathrm{O}_{2}$-induced cytotoxicity. Moreover, pretreatment with EA, EtOH and EtOH/wt extracts of $A$. ciniformis lead to a decrease in the reactive oxygen species (ROS) generation. Taken together our observation indicated that nontoxic concentration of different extracts of $A$. ciniformis has protective effect on $\mathrm{H}_{2} \mathrm{O}_{2}$-induced cytotoxicity in $\mathrm{H} 9$ c2 cells.

\section{Introduction}

Artemisia biennis Willd. and A. ciniformis Krasch. \& Popov ex Poljakov. (Compositae) grow wildly in Iran [1]. Analysis of the essential oils from the aerial parts of A. biennis growing in Iran and western Canada revealed the presence of camphor and $[\mathrm{E}]$ beta-farnesene as the major constituents, respectively $[2,3]$. Myrcene [4] and davanone [5] have been reported as the main constituent in the aerial parts oils of $A$. ciniformis

Cytotoxicity of some fractions of $A$. biennis and $A$. ciniformis as well as significant effects of ethanolic extracts of the species on in vitro leishmanicidal activity have been proved [6-8]. Iranshahi et al. [9] reported the presence of high amounts of sesquiterpene lactonesin A. ciniformis. Another study showed that antioxidant activity and total phenolic content of hydroethanolic extract of $A$. biennis were higher than those of other extracts [10].

Oxidative stress corresponds to an imbalance between the rate of oxidant production and degradation. It causes numerous biological effects ranging from alternation in signal transduction and gene expression to mutagenesis and finally cell death. It is well known that oxidative stress plays a significant role in the pathogenesis of heart dysfunctions [11]. In our previous study we evaluated the antioxidant activity and total phenolic content of different extracts of $A$. biennis using cell free systems [10]. In the current, study we aimed to examine the effects of $A$. biennis and $A$. ciniformis extracts on hydrogen peroxide $\left(\mathrm{H}_{2} \mathrm{O}_{2}\right)$-induced cytotoxicity and oxidative stress in $\mathrm{H} 9 \mathrm{c} 2$ cardiomyoblast cells. 


\section{Material and Methods}

2.1. Reagents and Chemicals. Hydrogen peroxide $\mathrm{H}_{2} \mathrm{O}_{2}, 3-$ (4,5-dimethylthiazol-2yl)-2,5-diphenyltetrazolium bromide (MTT), 2,5 dichlorofluorescin diacetate (DCF-DA) were bought from Sigma Aldrich (St Louis, MO, USA). Cell culture medium, penicillin-streptomycin, and fetal bovine serum (FBS) were purchased from Gibco (Gibco, Grand Island, NY, USA). All the solvents used for extraction were purchased from Caledon (Ontaria, Canada) and Scharlau (Sentmenate, Spain).

2.2. Plant Material. Aerial parts of A. ciniformis Krasch. \& Popov ex Poljakov. and A. biennis Willd. were collected from Tandoureh national park and Zoshk, respectively (Razavi Khorasan province, Iran), in September 2010. Samples were identified by Dr Valiollah Mozaffarian (Research Institute of Forest and Rangelands, Tehran, Iran). The voucher specimen (Nos. 12569 and 12570) have been deposited in the herbarium, Department of Pharmacognosy, Faculty of Pharmacy, Mashhad University of Medical Sciences, Mashhad, Iran.

2.3. Preparation of Extracts and Fractions. The dried powdered aerial parts $(80 \mathrm{~g})$ of $A$. biennis and A. ciniformis were extracted with petroleum ether (40-60) (PE), dichloromethane (DCM), ethyl acetate (EA), ethanol (EtOH) and ethanol-water $(1: 1 \mathrm{v} / \mathrm{v})(\mathrm{EtOH} / \mathrm{wt})$, respectively (Sequential maceration with ca. $3 \times 0.8 \mathrm{~L}$ of each solvent). The extracts were filtrated with filter paper and dried using rotary evaporator at a reduced pressure at a temperature below $45^{\circ} \mathrm{C}$ to yield 4.30, 5.60, 0.39, 1.28, and $8.10 \mathrm{~g}$ of each extract for $A$. biennis and 4.13, 9.66, 0.29, 2.54, and $16.08 \mathrm{~g}$ for A. ciniformis, respectively.

2.4. Cell Culture Conditions. Cardiac H9c2 cells are a clonal heart muscle cell line originated from embryonic rat hearts that presents many cardiomyocyte phenotypes [12]. The H9c2 cells maintained in Dubblico modified Eagle's medium (DMEM ATCC) with $10 \%(\mathrm{~V} / \mathrm{V})$ heat inactivated FBS, penicillin $\mathrm{G}(100 \mathrm{U} / \mathrm{mL})$ and streptomycin $(100 \mathrm{mg} / \mathrm{mL})$ at $37^{\circ} \mathrm{C}$ in $95 \% \mathrm{CO}_{2}$ humified incubator. The medium was changed 2-3 days and subcultured when the cell population density reached to $70-80 \%$ confluence. Cells were seeded at an appropriate density according to each experimental design.

2.5. Cell Viability Assay. Cellular toxicities of hydrogen peroxide and different extracts of $A$. biennis and $A$. ciniformis were analysed in H9c2 cells using MTT methods. Four sets of experiments were performed at standard culture conditions: (1) untreated control cells, (2) cells were treated with different concentrations of $A$. biennis and A. ciniformis $(10-50 \mu \mathrm{g} / \mathrm{mL})$, (3) cells were treated with different concentrationsof hydrogen peroxide (25-250 $\mu \mathrm{M})$, and (4) cells were pretreated with different concentrations of extracts for $24 \mathrm{~h}$, then medium was changed and cells were treated with $\mathrm{IC}_{50}$ concentration of hydrogen peroxide for another $24 \mathrm{~h}$. Viability of cells were analyzed using MTT methods. Briefly, after treatment,

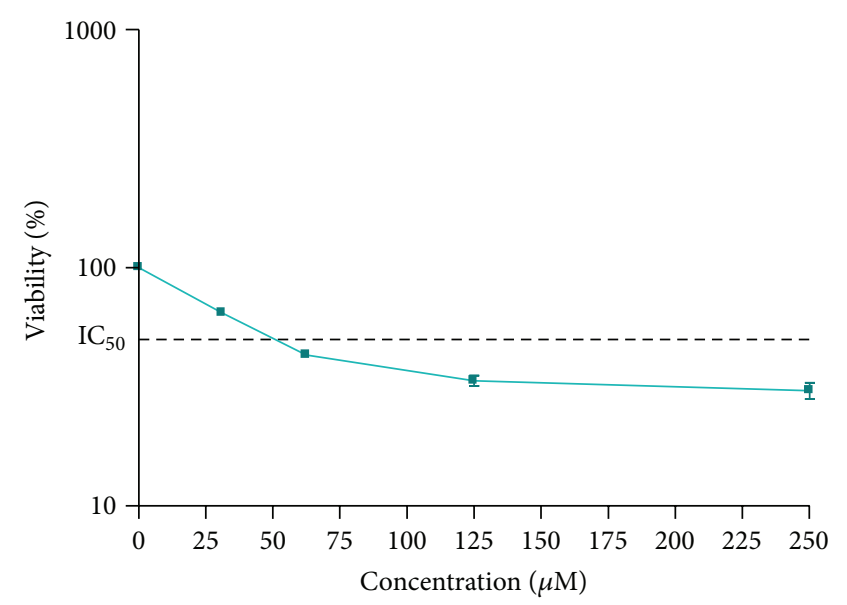

Figure 1: The effect of $\mathrm{H}_{2} \mathrm{O}_{2}$ on $\mathrm{H} 9 \mathrm{c} 2$ cell viability. The cell viability was determined by MTT assay as described in material and methods. Data are expressed as the mean \pm SEM of three separate experiments $(n=6)$.

$20 \mu \mathrm{L}$ of a $5 \mathrm{mg} / \mathrm{mL}$ MTT solution was added to each well. After $2 \mathrm{~h}$ incubation, the medium was carefully aspirated and the purple formazan crystals were solubilized with $100 \mu \mathrm{L}$ DMSO. Optical density was measured at $570 \mathrm{~nm}$ (reference wavelength $630 \mathrm{~nm}$ ) in a microplate reader (Bio-Tek, ELX 800 , USA). The absorbance of the untreated culture was set at $100 \%$.

2.6. Determination of Intracellular ROS. Intracellular ROS levels were examined using DCF-DA. DCF-DA is a nonfluorescent lipophilic ester that easily crosses the plasma membrane. Into the cytosol the acetate group is rapidly removed by unspecific esterases. The oxidation of this molecule to the fluorochrome DCF results in green fluorescence. The intensity of this fluorescence is generally considered to reflect the level to which ROS are present [12].

After seeding for $24 \mathrm{~h}, \mathrm{H} 9 \mathrm{c} 2$ cells were washed with PBS buffer ( $\mathrm{pH}$ 7.4). The cells pretreated with test samples for $24 \mathrm{~h}$ were then treated with $\mathrm{H}_{2} \mathrm{O}_{2}$ for an additional $24 \mathrm{~h}$. After washing with PBS, the cells were incubated with $20 \mu \mathrm{L}$ DCF$\mathrm{DA}$ at $37^{\circ} \mathrm{C}$ for $30 \mathrm{~min}$. The percentage of DMSO insolution did not exceed from $0.5 \%$. After incubation, cells were lysed with Triton X-100. The fluorescence was measured at an excitation wavelength of $488 \mathrm{~nm}$ and an emission wavelength of $528 \mathrm{~nm}$ using a fluorescence microplate reader (BioTek, H1M, USA).

2.7. Statistical Analysis. Each experiment was performed at least three times and the results were presented as mean \pm S.E.M. One-way analysis of variance (ANOVA) followed by Turkey's test was used to compare the differences between means. A probability value of $P<0.05$ was considered to be statistically significant. 


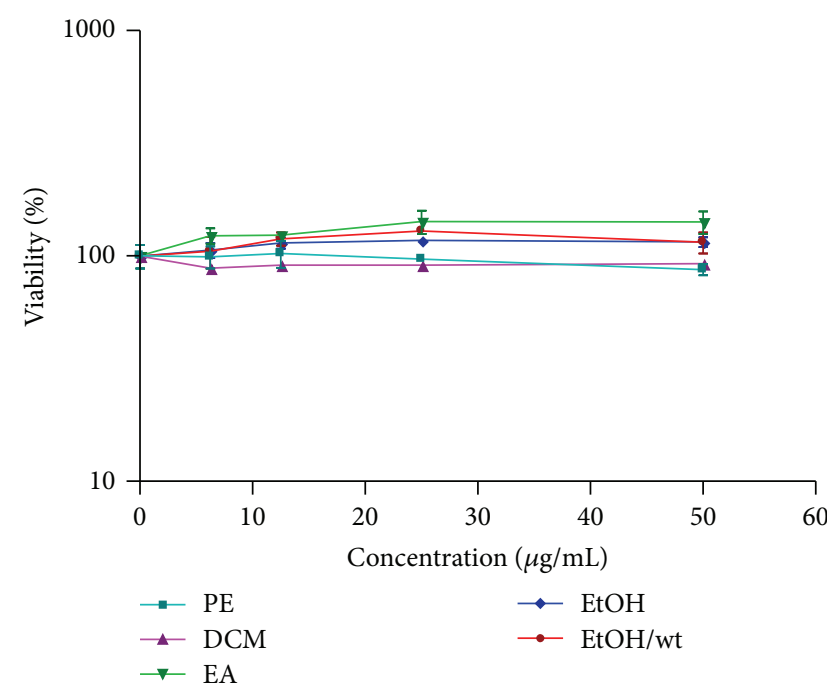

(a)

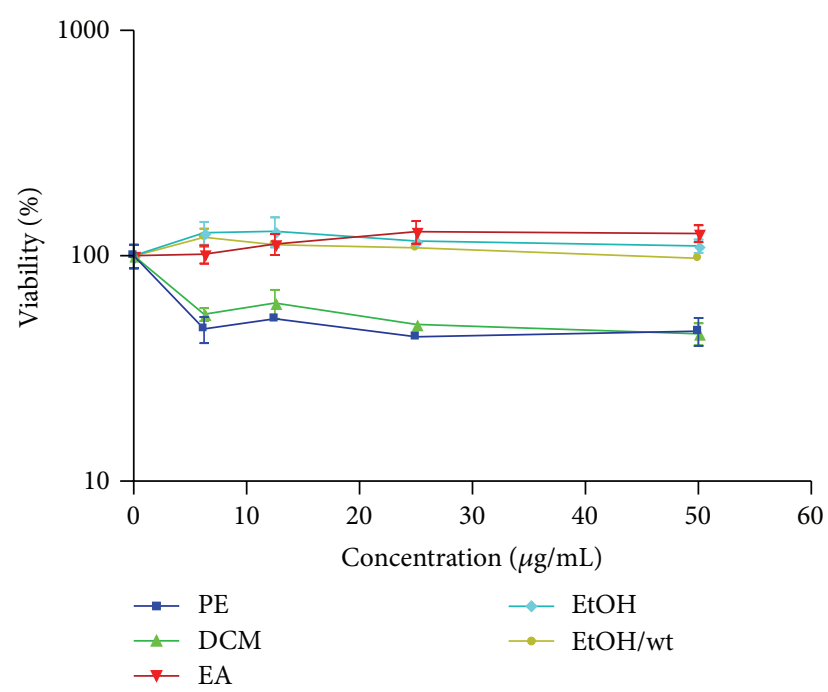

(b)

Figure 2: Cell viability of H9c2 cells after exposure to (a) A. biennis and (b) A. ciniformis Cells were treated with different concentration of extracts for $24 \mathrm{~h}$. The cell viability was determined by MTT assay. Data are expressed as the mean \pm SEM of three separate experiments $(n=6)$.

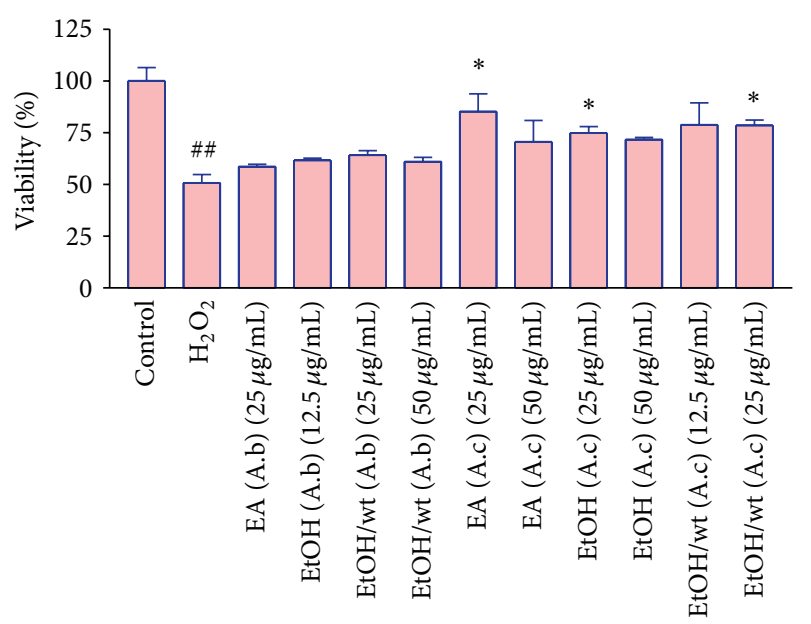

FIgure 3: The effect of different extracts of $A$. biennis and A. ciniformis on $\mathrm{H}_{2} \mathrm{O}_{2}$-induced cytotoxicity in $\mathrm{H} 9 \mathrm{c} 2$ cells. Cell pretreated with different extracts of $A$. biennis and $A$. ciniformis for $24 \mathrm{~h}$ before exposure to $62.5 \mu \mathrm{M}$ of $\mathrm{H}_{2} \mathrm{O}_{2}$. Data are expressed as the mean \pm SEM of three separate experiments $(n=6) .{ }^{\# \#} P<0.01$ versus control, ${ }^{*} P<0.05$, versus $\mathrm{H}_{2} \mathrm{O}_{2}$ treated cells.

\section{Results}

3.1. Cell Viability after Exposure to $\mathrm{H}_{2} \mathrm{O}_{2}$, A. biennis, and A. ciniformis Extracts Alone. The viability of H9c2 cardiomyoblast cells was evaluated after $24 \mathrm{~h}$ exposure to different concentrations of $\mathrm{H}_{2} \mathrm{O}_{2}$. Cell viability was evaluated by the MTT method. As shown in Figure 1, $\mathrm{H}_{2} \mathrm{O}_{2}$-induced cytotoxicity was dose dependent. The mean $\pm \mathrm{SEM} \mathrm{IC}_{50}$ value was $62.5 \pm 0.034 \mu \mathrm{M}$ for $24 \mathrm{~h}$ exposure to $\mathrm{H}_{2} \mathrm{O}_{2}$. In order to set extracts at concentrations which are nontoxic to cells but could prevent $\mathrm{H}_{2} \mathrm{O}_{2}$-induced cytotoxicity, we also examined

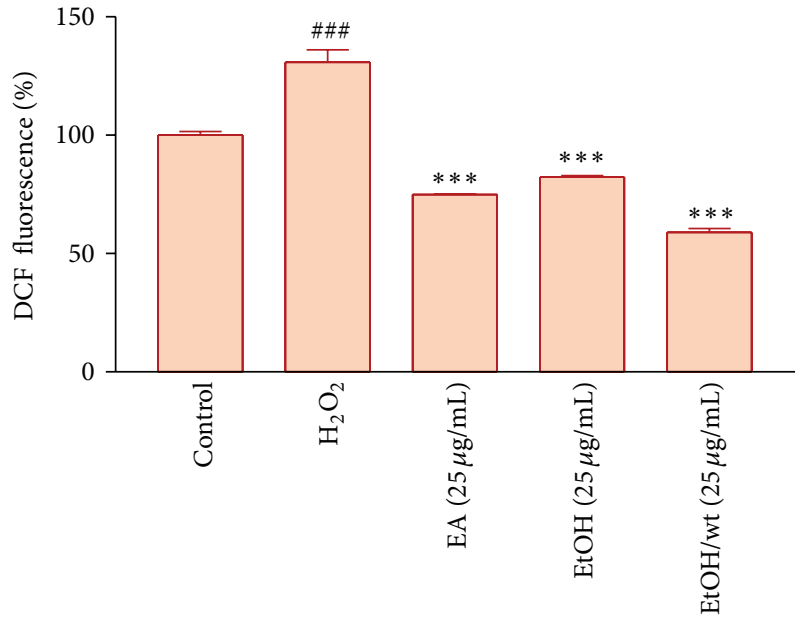

Figure 4: The effect of different extracts of $A$. ciniformis pretreatment on $\mathrm{H}_{2} \mathrm{O}_{2}$-induced ROS generation. Data are expressed as the mean \pm SEM of three separate experiments $(n=4)$. ${ }^{\# \# \# ~} P<0.001$ versus Control, and ${ }^{* * *} P<0.001$ versus $\mathrm{H}_{2} \mathrm{O}_{2}$-treated cells.

the effects of different concentrations of $A$. biennis and $A$. ciniformis extracts on cell viability in H9c2 cells.

Figure 2 clearly revealed that $24 \mathrm{~h}$ treatment with $\mathrm{PE}$, DCM, EA, EtOH, and EtOH/wt extracts of $A$. biennis had no cytotoxic effect at the concentrations up to $50 \mu \mathrm{g} / \mathrm{mL}$, while $24 \mathrm{~h}$ exposure to DCM and PE extracts of $A$. ciniformis induced dose response cytotoxicity.

\subsection{Effect of Pretreatment with Different Extracts of A. biennis} and $A$. ciniformis on $\mathrm{H}_{2} \mathrm{O}_{2}$ Induced Cell Death. For evaluation of effect of pretreatment with different extracts on $\mathrm{H}_{2} \mathrm{O}_{2}$ induced cytotoxicity, $\mathrm{H} 9 \mathrm{c} 2$ cells were pretreated for $24 \mathrm{~h}$ with 
nontoxic concentrations of extracts, then the medium was changed and cells treated with $\mathrm{IC}_{50}$ concentration $(62.5 \mathrm{mM})$ of $\mathrm{H}_{2} \mathrm{O}_{2}$ for another $24 \mathrm{~h}$. As shown in Figure $1, \mathrm{H}_{2} \mathrm{O}_{2}$ treatment significantly decreased cell viability to $50 \pm 2.2 \%$ of control. Adding EA, EtOH, and EtOH/wt extracts of A. ciniformis $(25 \mu \mathrm{g} / \mathrm{mL})$ before $\mathrm{H}_{2} \mathrm{O}_{2}$ treatment increased the cell viability to $76 \pm 4.53,72 \pm 1.25$ and $82 \pm 3.21 \%$ of control, respectively (Figure 3 ). Other extracts were not able to protect $\mathrm{H} 9 \mathrm{c} 2$ cells against $\mathrm{H}_{2} \mathrm{O}_{2}$-induced cytotoxicity.

3.3. Effect of EA, EtOH, and EtOH/wt Extracts of A. ciniformis on ROS Induced by $\mathrm{H}_{2} \mathrm{O}_{2}$ in $\mathrm{H} 9 \mathrm{c} 2$ Cardiac Muscle Cells. In order to measure oxidative stress induced by $\mathrm{H}_{2} \mathrm{O}_{2}$, fluorescent dye DCF-DA was used to measure ROS generation. As anticipated adding $\mathrm{H}_{2} \mathrm{O}_{2}$ to $\mathrm{H} 9 \mathrm{c} 2$ cells caused a significant increase in ROS level. Therefore, cardiomyoblast cells are probably killed due to oxidative stress, since $\mathrm{H}_{2} \mathrm{O}_{2}$ increases intracellular ROS levels. We investigated the inhibitory effect of different extracts on ROS production in the presence of $\mathrm{H}_{2} \mathrm{O}_{2}$. Pretreatment with EA, EtOH, and EtOH/wt extracts of A. ciniformis decreased intra cellular ROS levels in H9c2 cells, significantly. These results indicate that the aforementioned extracts have potential for prevention of ROS mediated events (Figure 4).

\section{Discussion}

Oxidative stress is considered to be an important condition to promote cell death in response to a variety of signals and pathophysiological condition [13]. It results from increased formation of ROS and/or decreased antioxidant store. Oxidative stress can be identified in most of the key stages in the pathophysiology of atherosclerosis and the main clinical manifestations of cardiovascular disease [14, 15]. Previous reports demonstrated thatanti-oxidant natural substances including herbal medicines could inhibit ROS generation [16].

In the current study we examined the protective effect of different extracts of $A$. biennis and $A$. ciniformis on the cytotoxicity induced by $\mathrm{H}_{2} \mathrm{O}_{2}$. The obtained results showed that only $\mathrm{EA}, \mathrm{EtOH}$, and $\mathrm{EtOH} /$ wt extracts of $A$. ciniformis are able to protect $\mathrm{H} 9 \mathrm{c} 2$ cardiomyoblast cells against $\mathrm{H}_{2} \mathrm{O}_{2}$ cytotoxicity.

Next, it was investigated whether pretreatment with above mentioned extracts had an effect on ROS generation by $\mathrm{H}_{2} \mathrm{O}_{2}$. The obtained results showed that pretreatment with $\mathrm{EA}, \mathrm{EtOH}$, and $\mathrm{EtOH} /$ wt extracts of $A$. ciniformis leads to a decrease in the ROS generation. One possible explanation for the effect of EA, EtOH, and EtOH/wt extracts of $A$. ciniformis on the oxidative stress induced by $\mathrm{H}_{2} \mathrm{O}_{2}$ concerns its polyphenolic content, because it is known that plant-derived polyphenolics are potent antioxidants and free radical scavengers [17].

Despite the fact that hydro ethanolic extract of $A$. biennis showed potent antioxidant effects using free radical scavenging methods it was not able to protect $\mathrm{H} 9 \mathrm{c} 2$ cells from cytotoxicity induced by $\mathrm{H}_{2} \mathrm{O}_{2}$ in the current study [10]. This is due to the actual antioxidant activity in physiological conditions such as specific target radicals, localization in different phases and their possible interaction. Therefore, cell free methods may not be sufficient to assessment of antioxidant properties of phytochemicals. Taken together, our data suggested that $\mathrm{EA}, \mathrm{EtOH}$, and $\mathrm{EtOH} /$ wt extracts of A. ciniformis, protected cardiomyoblasts against $\mathrm{H}_{2} \mathrm{O}_{2}$ induced cell death by a mechanism believed to be free radical scavenging and/or the inhibition of reactive oxygen species. Thus, EA, EtOH, and $\mathrm{EtOH} /$ wt extracts of $A$. ciniformis contains principals that may be useful for the prevention and treatment of cardiovascular diseases associated with ROS. Polyphenolics [18], nitrogen containing compounds [19], Polysaccharide fractions [20] and terpenoids [21] are examples of different classes of plant-derived antioxidants. Isolation and characterization of the active and/or major components as well as further studies to determine the molecular mechanisms by which the extracts exert their cardioprotective role are needed.

\section{Conflict of Interests}

The authors declares there is no conflict of interests.

\section{Acknowledgment}

This work was performed in partial fulfillment of the requirements for Pharm. D. of Maryam Jamshidi, Kermanshah University of Medical Sciences, Kermanshah, Iran.

\section{References}

[1] V. Mozaffarian, A Dictionary of Iranian Plant Names, Farhang Moaser, Tehran, Iran, 1998.

[2] F. Nematollahi, A. Rustaiyan, K. Larijani, M. Nadimi, and S. Masoudi, "Essential oil composition of Artemisiabiennis willd. and Pulicariaundulata (L.) C.A. Mey., two compositae herbs growing wild in Iran," Journal of Essential Oil Research, vol. 18, no. 3, pp. 339-341, 2006.

[3] D. Lopes-Lutz, D. S. Alviano, C. S. Alviano, and P. P. Kolodziejczyk, "Screening of chemical composition, antimicrobial and antioxidant activities of Artemisia essential oils," Phytochemistry, vol. 69, no. 8, pp. 1732-1738, 2008.

[4] A. Rustaivan, S. Masoudi, and M. Kazemi, "Volatile oils constituents from different parts of Artemisia ciniformis Krasch. et M. Pop. ex Poljak and Artemisia incana (L.) Druce. from Iran," Journal of Essential Oil Research, vol. 19, no. 6, pp. 548-551, 2007.

[5] A. Firouzni, H. Vahedi, F. Sabbaghi, and M. Bigdeli, "Composition of the essential oil of Artemisia ciniformis, A. kopetdaghensis, and A. khorasanica in Iran," Chemistry of Natural Compounds, vol. 44, no. 6, pp. 804-806, 2008.

[6] A. Emami, S. H. Zamani Taghizadeh Rabe, A. Ahi, and M. Mahmoudi, "Study on toxic effects of Artemisisa spp. fractions from Iran on human cancer cell lines," Journal of Zanjan University of Medical Sciences and Health Services, vol. 18, no. 70, pp. 58-67, 2010.

[7] S. Z. Taghizadeh Rabe, M. Mahmoudi, A. Ahi, and S. A. Emami, "Antiproliferative effects of extracts from Iranian Artemisia species on cancer cell lines," Pharmaceutical Biology, vol. 49, no. 9, pp. 962-969, 2011. 
[8] S. A. Emami, S. Z. T. Rabe, A. Ahi, and M. Mahmoudi, "Inhibitory activity of eleven Artemisia species from Iran against Leishmania major parasites," Iranian Journal of Basic Medical Sciences, vol. 15, no. 2, pp. 807-811, 2012.

[9] M. Iranshahi, S. A. Emami, and M. Mahmoud-Soltani, "Detection of sesquiterpene lactones in ten Artemisia species population of Khorasan provinces," Iranian Journal of Basic Medical Sciences, vol. 10, pp. 183-188, 2007.

[10] T. Hatami, S. A. Emami, S. S. Miraghaee, and M. Mojarrab, "Total phenolic contentsand antioxidant activities of different extracts and fractions from the aerial parts of Artemisia biennis Willd," Iranian Journal of Basic Medical Sciences. In press.

[11] B. Herrera, M. M. Murillo, A. Álvarez-Barrientos, J. Beltrán, M. Fernández, and I. Fabregat, "Source of early reactive oxygen species in the apoptosis induced by transforming growth factor$\beta$ in fetal rat hepatocytes," Free Radical Biology and Medicine, vol. 36, no. 1, pp. 16-26, 2004.

[12] M. Karlsson, T. Kurz, U. T. Brunk, S. E. Nilsson, and C. I. Frennesson, "What does the commonly used DCF test for oxidative stress really show?" Biochemical Journal, vol. 428, no. 2, pp. 183-190, 2010.

[13] J. M. Matés and F. M. Snchez-Jiménez, "Role of reactive oxygen species in apoptosis: implications for cancer therapy," The International Journal of Biochemistry \& Cell Biology, vol. 32, no. 2, pp. 157-170, 2000.

[14] O. Sorg, "Oxidative stress: a theoretical model or a biological reality?” Comptes Rendus, vol. 327, no. 7, pp. 649-662, 2004.

[15] R. Schnabel and S. Blankenberg, "Oxidative stress in cardiovascular disease: successful translation from bench to bedside?" Circulation, vol. 116, no. 12, pp. 1338-1340, 2007.

[16] E. D. Brookins Danz, J. Skramsted, N. Henry, J. A. Bennett, and R. S. Keller, "Resveratrol prevents doxorubicin cardiotoxicity through mitochondrial stabilization and the Sirtl pathway," Free Radical Biology and Medicine, vol. 46, no. 12, pp. 1589-1597, 2009.

[17] K. Ishige, D. Schubert, and Y. Sagara, "Flavonoids protect neuronal cells from oxidative stress by three distinct mechanisms," Free Radical Biology and Medicine, vol. 30, no. 4, pp. 433-446, 2001.

[18] A. L. Miller, "Antioxidant flavonoids: structure, function and clinical usage," Alternative Medicine Review, vol. 1, no. 2, pp. 103-111, 1996.

[19] G. Drolet, E. B. Dumbroff, R. L. Legge, and J. E. Thompson, "Radical scavenging properties of polyamines," Phytochemistry, vol. 25, no. 2, pp. 367-371, 1986.

[20] J. Wang, Q. Zhang, Z. Zhang, and Z. Li, "Antioxidant activity of sulfated polysaccharide fractions extracted from Laminaria japonica," International Journal of Biological Macromolecules, vol. 42, no. 2, pp. 127-132, 2008.

[21] J. Das, A. A. Mao, and P. J. Handique, “Terpenoid compositions and antioxidant activities of two Indian valerian oils from the Khasi Hills of North-east India," Natural Product Communications, vol. 6, no. 1, pp. 129-132, 2011. 

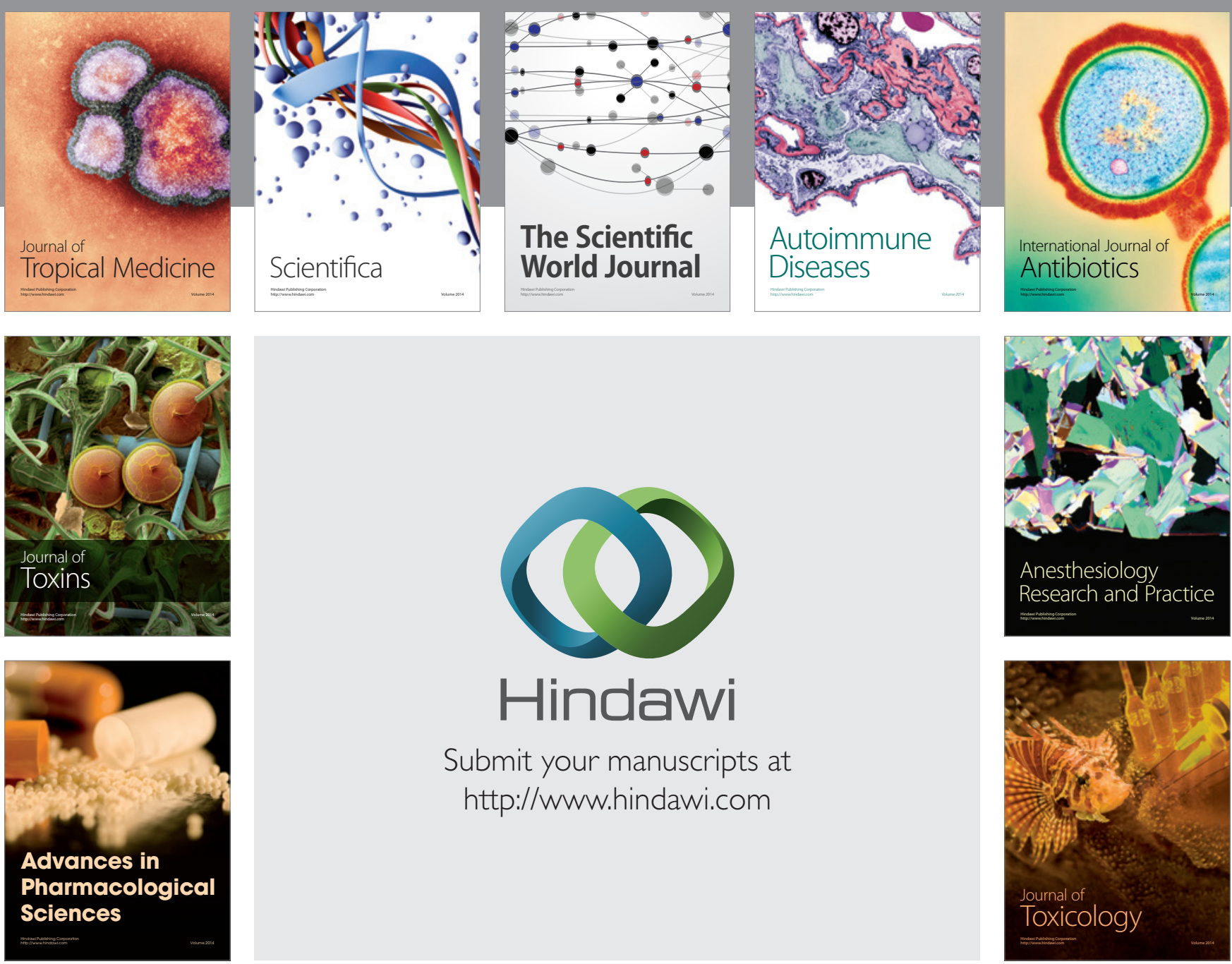

\section{Hindawi}

Submit your manuscripts at

http://www.hindawi.com
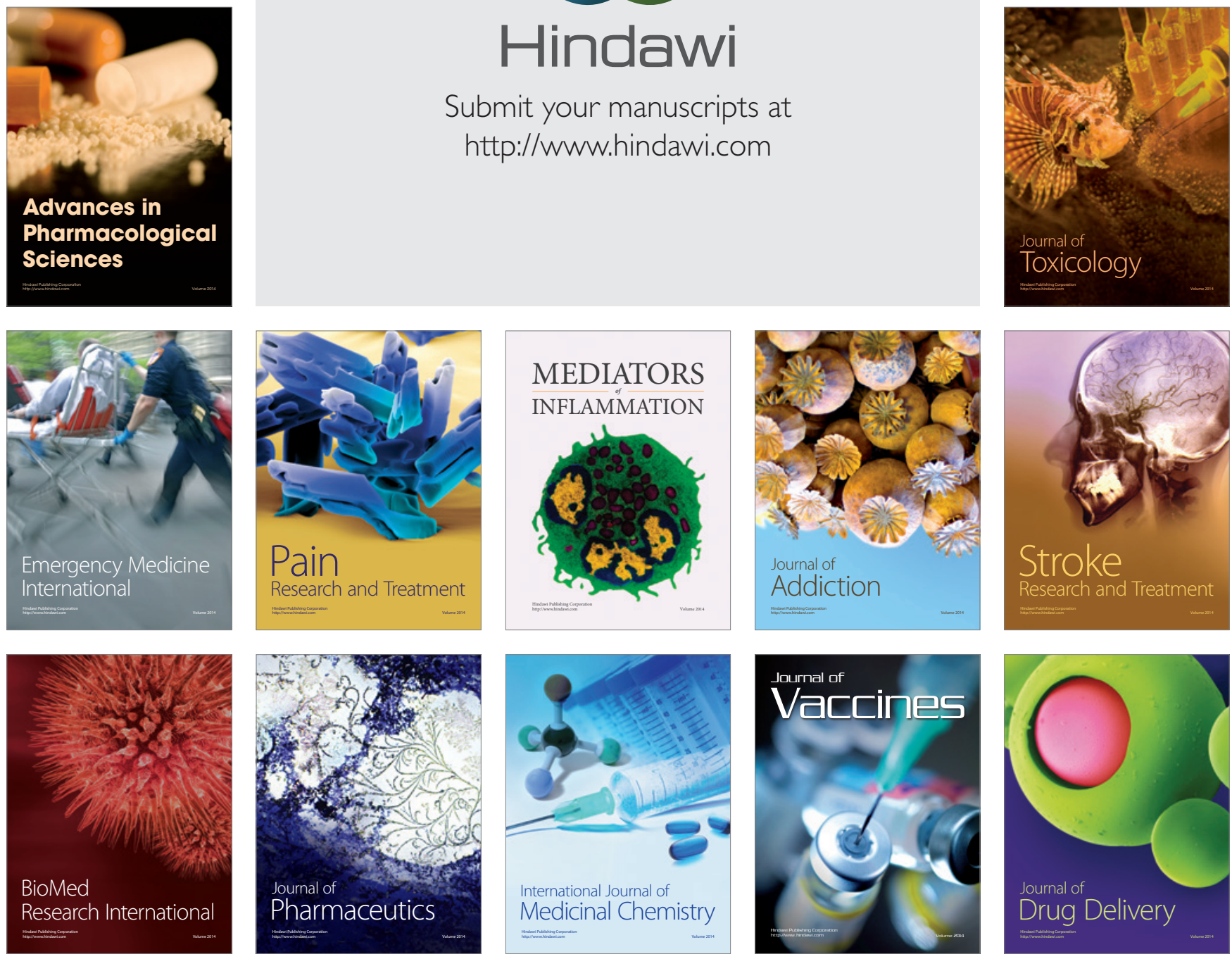